\title{
PELATIHAN PEMBUATAN TEPUNG PISANG GOROHO (Musa acuminata, SP) DAN CARA PEMBUATAN KUE BISCUIT DARI TEPUNG PISANG GOROHO
}

\author{
Anatje Lihiang ${ }^{1)}$, Meity Sasinggala ${ }^{2)}$ \\ Fakultas Matematika dan Ilmu Pengetahuan Alam, Universitas Negeri Manado
}

\begin{abstract}
ABSTRAK
Pisang goroho (Musa acuminate, SP) adalah salah satu tanaman endemic yang ada di Sulawesi Utara khususnya di Minahasa. Umumnya pisang goroho dikonsumsi dengan cara digoreng atau direbus. Sekarang ini pisang goroho dapat diolah menjadi tepung dan dibuat berbagai macam kue basah maupun kue kering misalnya cake, bronis, biscuit dan lain-lain. Menurut Sondakh (1990) tepung pisang goroho mengandung nilai gizi pati $80.89 \%$, Protein $2.89 \%$, lemak $0.67 \%$ dan serat kasar 2\%. Dari data tersebut terbukti potensi pengolahan pisang goroho menjadi tepung memberi peluang pengembangan yang lebih bervariasi yang secara tidak langsung ikut membantu percepatan pencapaian program ketahanan pangan Nasional. Target luaran yang diharapkan dari kegiatan PKM ini adalah semua mitra PKK dapat menjadi pengusaha kue biscuit berbahan pokok tepung pisang goroho dengan menggunakan kotak kemasan yang sudah disepakati bersama serta semua mitra PKK dapat mengolah keuangan/managemen dan pembuatan cash flow usaha.
\end{abstract}

Kata kunci: Tepung pisang goroho (Musa acuminate, SP), PKK, biscuit

\section{PENDAHULUAN}

\section{A. Analisis Situasi}

Sulawesi Utara sebagai pintu gerbang Indonesia Bagian Timur memiliki beraneka ragam tanaman endemic, salah satu tanaman yang tidak ditemui di daerah lain adalah tanaman pisang goroho (Musa acuminate, $s p$ ). Pisang goroho merupakan jenis pisang spesifik local di daerah Sulawesi Utara khususnya di daerah Minahasa. Tingkat konsumsi pisang goroho di daerah Sulawesi Utara saat ini meningkat cukup tinggi karena informasi dari mulut kemulut tentang manfaat pisang ini, umumnya pisang goroho dikonsumsi dengan cara digoreng dan direbus.

Di Manado, jenis olahan ini sekarang mulai disajikan dalam menu di hotel-hotel berbintang, selain itu juga menjadi menu faforit di beberapa bisnis makanan mulai dari pedagang gerobak sampai pada restoran di lokasi perbelanjaan. Dahulu, sebelum pisang goroho diperdagangkan secara komersil, pisang goroho hanya dapat ditemukan pada waktu-waktu tertentu saja, seperti pada saat masyarakat melakukan seremonial panen padi serta acara-acara lain yang sifatnya selamatan, arisan dan syukuran.

Pengolahan pisang goroho menjadi tepung memberi peluang pengembangan yang lebih bervariasi, yang secara tidak langsung ikut membantu percepatan pencapaian program ketahanan pangan Nasional. Ketahanan pangan yang dilakukan untuk memaksimalkan produksi dan konsumsi bahan pangan local sumber karbohidrat non beras dan non terigu yang menjadi prioritas pemerintah terutama dalam bidang diversifikasi. Usaha diversifikasi konsumsi pangan saat ini tidak sekedar untuk menyediakan pangan yang beragam dan bergizi, tetapi sudah mulai berkembang sampai pada pertimbangan manfaat bagi kesehatan.

Berdasarkan penelitian yang pernah dilakukan oleh Sondakh (1990), tepung pisang goroho mengandung nilai gizi Pati $80,89 \%$, Protein $2,89 \%$, lemak $0,6 \%$, total gula $1,83 \%$, air $11,99 \%$, dan serat kasar \pm 
2\%. Dari data tersebut terbukti bahwa potensi pengembangan pisang goroho sebagai makanan alternative bersumber karbohidrat sangat besar peluangnya karena kandungan pati cukup tinggi yaitu $80,89 \%$, dan gula $1,83 \%$ sehingga aman dikonsumsi oleh orang yang menderita penyakit gula (Diabetes militus). Sayangnya, masyarakat di Sulawesi Utara belum mengetahui cara pembuatan tepung dari bahan pisang goroho. Sementara tepung pisang goroho dapat digunakan untuk berbagai macam produk olahan, seperti kue basa dan kue kering misalnya cake, biscuit, bronis.

Mitra dalam PKM ini adalah pengusaha kecil pembuatan dan penjual kue basa dan kue kering yang terdaftar sebagai anggota pada kelompok PKK lingkungan 2 dan lingkungan 3 Desa Rasi. Pembuatan dan penjualan kue berkembang sejak tahun 1998 menjadi sebuah usaha yang banyak diikuti oleh kaum perempuan di Desa Rasi Kabupaten Minahasa Tenggara. Usaha penjualan kue dapat memberikan kontribusi pendapatan bagi rumahtangga pelakunya dan pemanfaatan waktu luang perempuan untuk melakukan usaha ini. Dengan demikian perempuan memiliki pendapatan yang dapat membantu ekonomi rumahtangga/keluarga.

Berdasarkan informasi dari Dinas Koperasi dan UKM jumlah perempuan pedagang dan pengusaha kue di lokasi ini berkisar 6 kios/usaha yang digeluti oleh perempuan pedesaan (Dinas Koperasi dan Pengusaha Kecil Menengah, Kabupaten Minahasa Tenggara, 2013). Kondisi tersebut memperlihatkan bahwa usaha sektor informal ini mampu mengangkat citra makanan yang berasal dari tepung pisang goroh atau tanaman lokal dan mampu membuka peluang usaha khususnya bagi perempuan pedesaan. Pengembangan usaha ini dapat meningkatkan potensi perekonomian pedesaan dan memberikan kontribusi bagi peningkatan pendapatan rumahtangga perempuan dan peningkatan pendapatan daerah.

Faktor lain yang menunjang berkembangnya usaha ini yaitu letak/posisi Desa Rasi Kecamatan Ratahan, merupakan wilayah perlintasan antar kabupaten di Propinsi Sulawesi Utara, maupun antar propinsi. Tepung pisang goroho dan kue biskuit yang berbahan dasar pisang goroho ini menjadi salah satu jenis oleh-oleh/buah tangan bagi masyarakat yang melintasi wilayah tersebut. Oleh karena itu, perlu mendapat perhatian karena dapat menjadi ciri khas atau ikon bagi Kabupaten Minahasa Tenggara khususnya dan mampu mengangkat citra makanan lokal/tradisional di Sulawesi Utara pada umumnya.

Usaha pembuatan tepung pisang goroho dan penjualan kue biskuit kebanyakan diusahakan oleh kaum perempuan dikategorikan sebagai usaha sektor informal karena memiliki ciri-ciri antara lain :

1. Seluruh aktivitasnya bersandar pada sumber daya lokal. Bahan-bahan (tepung pisang goroho) dan sarana (cetakan, tungku dan kayu bakar) dalam pembuatan kue biskuit tersedia di sekitar lokasi penjualan.

2. Ukuran (skala) usaha umumnya kecil dan aktivitasnya merupakan usaha keluarga.

3. Menggunakan teknologi yang sederhana, bahkan teknologinya masih tradisional dan bersifat padat karya.

4. Modal yang digunakan untuk berusaha dan perputaran usaha relatif kecil.

5. Tenaga kerja yang bekerja umumnya adalah berasal dari anggota PKK.

6. Aktivitas mereka dalam sektor ini belum/tidak menggunakan bantuan atau fasilitas yang disediakan oleh pemerintah.

7. Sebagian besar produksi dan jasa mereka dinikmati oleh masyarakat berpenghasilan rendah serta sebagian kecil masyarakat golongan menengah. 
Kebanyakan pengusaha kue biskuit yang ada di lokasi ini dapat dikategorikan sebagai usaha berskala 'kecil'. Modal awal membuka usaha kue biskuit rata-rata 1 juta rupiah untuk bangunan kios dan sarananya. Untuk usaha kecil penjualan kue biskuit biasanya menghabiskan adonan rata-rata 1 $\mathrm{kg}$ tepung pisang goroho, dan gula merah 1 buah, hasil yang diperoleh yaitu 150 biji (15 kotak). Di dalam satu kotak berisi 10 biji. Harga penjualan per kotak yaitu 10.000 rupiah. Jadi, apabila semua kotak terjual habis, maka pedagang akan memperoleh harga omzet sebesar Rp. 150.000. Biaya yang diperlukan dalam pembuatan kue biskuit sebanyak 150 biji itu sebesar Rp. 75.000, sehingga keuntungan yang diperoleh sekitar 50\% (Hasil wawancara dengan calon Mitra, 2015).

Upaya untuk meningkatkan omzet pengusaha berskala kecil sulit dilakukan. Hal itu terjadi oleh karena adanya kendala utama yaitu: banyaknya jumlah pengusaha kue biscuit berbahan dasar tepung terigu yang ada di sekitar lokasi ini yaitu 6 usaha/kios yang bersaing menawarkan produk yang sama. Rasa kue biskuit yang dibuat pengusaha sama yaitu rasa original pada semua kios. Tidak ada variasi rasa yang berbeda.

Upaya lain yang dapat dilakukan untuk meningkatkan omzet penjualan suatu produk yaitu dengan memperbaiki kualitas dari bahan kue biskuit tersebut dengan menggantikan tepung terigu diganti dengan tepung pisang gorogo, yang bergizi dan kaya akan zat yang mengandung antioksidan dan juga memperbaiki kotak/dos kemasan suatu produk. Kotak kemasan suatu produk bukan hanya berfungsi untuk menjaga kebersihan dan bentuk suatu produk, melainkan juga dapat berfungsi sebagai ajang promosi bagi produk tersebut. Oleh karena itu, kotak kemasan suatu produk harus menarik, berkualitas baik dan informatif.
Pengusaha kue biskuit baik yang berskala kecil maupun besar di Desa Rasi masih mengemas produk kue biskuit dalam kotak yang banyak diperjual belikan di pasaran. Kotak kemasan yang digunakan kurang berkualitas (tipis) sehingga memungkinkan terjadi kerusakan dalam perjalanan. Selain itu tidak ada informasi nama usaha, nama produk dan informasi lainnya pada kotak kemasan. Padahal kotak kemasan yang berkualitas dan informatif dapat menjadi promosi untuk memperkenalkan usaha dan dapat meningkatkan omzet penjualan.

Permasalahan tersebut tampaknya belum terpikirkan oleh pengusaha kue biskuit yang ada di desa ini. Hal ini terjadi karena kurangnya pengetahuan pengusaha kue biskuit mengenai hal-hal yang berkaitan dengan pengolahan kue yang berbahan dasar tepung pisang goroho, pada hal pisang goroho di desa Rasid sangat banyak serta kurangnya pengetahuan pengusaha kue biskuit mengenai pengelolaan/manajemen usaha yang baik dan benar, termasuk pengelolaan keuangan. Melalui program training/pelatihan bagi mitra usaha kue biskuit, mereka akan menjadi pengusaha yang memiliki skills yang lebih baik, mampu menciptakan produk baru/modifikasi rasa, bentuk, warna dan meningkatkan omzet penjualan produk.

Dengan adanya mitra dalam jumlah yang cukup banyak di lingkungan desa Rasid, diharapkan mitra dapat mengembangkan usahanya serta dapat mengembangkan ketrampilan yang telah mereka peroleh kepada lingkungannya, sehingga lingkungan usaha di wilayah tersebut nantinya menjadi berkembang. Dengan adanya perkembangan usaha ini diharapkan nantinya bisa menumbuh kembangkan perekonomian di wilayah Desa Rasid khususnya dan Kabupaten Minahasa Tenggara pada umumnya.

\section{Profil Kelompok PKK Desa Rasi}


Di Desa Rasid Ratahan terdapat kelompok ibu-ibu PKK yang terdiri dari 11 kelompok PKK. Dua dari kelompok PKK tersebut adalah mitra dalam program kegiatan Hibah PKM yang berlokasi di Desa Rasi. Pemilihan kedua kelompok PKK berdasarkan usaha kue yang dikelolah anggotanya yaitu pada umumnya berusaha kue jajanan yang berbahan dasar dari tepung terigu..

Kelompok PKK yang pertama adalah kelompok PKK lingkungan 2 yang beranggotakan sebanyak 20 orang, yang di ketuai oleh ibu Henny. Kelompok kue mitra yang kedua adalah kelompok PKK lingkungan 3 dan beranggotakan 18 orang yang diketuai oleh ibu Lee.

Tingkat pendidikan merupakan factor yang berperan penting, karena pendidikan mempengaruhi cara berfikir seseorang. Pendidikan dalam hal ini berupa pendidikan formal yang telah dijalani seseorang. Semakin tinggi pendidikan seseorang, maka semakin besar kemampuan mereka dalam menerima inovasi baru dibanding mereka yang berpendidikan rendah. Tingkat pendidikan diduga ikut juga berpengaruh terhadap tingkat partisipasi seseorang dalam cara berfikir dan pengambilan keputusan.

Tingkat pendidikan merupakan salah satu indicator kesejahteraan, karena pendidikan berfungsi untuk meningkatkan taraf hidup dan kesejahteraan (Anonim, 1995). Pendidikan anggota kelompok PKK kedua mitra tidak ada yang mencapai sarjana, namun tidak ada pula yang tidak bersekolah. Tingkat pendidikan paling banyak pada tingkat SMA yaitu 11 orang dan berikutnya pada tingkat SMP 9 orang dan SD 8 orang.

\section{B. Permasalahan Kelompok}

Biskuit adalah sejenis makanan yang terbuat dari tepung terigu dengan penambahan bahan makanan lain, dengan proses pemanasan dan pencetakan. Sebagian besar biscuit yang ada di pasaran menggunakan bahan baku tepung terigu. Tepung terigu, tepung yang mempunyai kandungan protein yang rendah (Aninomous, 2012). Penggunaan tepung non terigu untuk pembuatan biscuit saat ini kurang di kembangkan. Pada hal tepung non terigu misalnya tepung pisang goroho yang banyak terdapat di daerah ini sangat baik untuk dijadikan bahan dasar kue biscuit karena tidak mengandung glutein.

Mitra dalam PKM ini adalah pengusaha pembuat dan penjual kue biskuit. Pembuatan dan penjualan kue biskuit berkembang sejak tahun 1998 menjadi sebuah usaha yang banyak diikuti oleh kaum perempuan di Desa Rasi, Kabupaten Minahasa Tenggara. Usaha penjualan kue biskuit dapat memberikan kontribusi pendapatan bagi rumahtangga pelakunya dan pemanfaatan waktu luang perempuan untuk melakukan usaha ini. Dengan demikian perempuan memiliki pendapatan yang dapat membantu ekonomi rumahtangga/keluarga.

Di antara 12 kabupaten yang ada di Propinsi Sulawesi Utara, usaha pembuatan dan penjualan kue biscuit yang berbahan dasar tepung pisang goroho hanya ditemukan di Kabupaten Minahasa Tenggara, khususnya di Desa Rasid. Berdasarkan informasi dari Dinas Koperasi dan UKM jumlah perempuan pedagang dan pengusaha kue biskuit di lokasi ini berkisar 6 kios/usaha yang digeluti oleh perempuan pedesaan (Dinas Koperasi dan Pengusaha Kecil Menengah, Kabupaten Minahasa Tenggara, 2016). Kondisi tersebut memperlihatkan bahwa usaha sektor informal ini mampu mengangkat citra makanan tradisional/lokal dan mampu membuka peluang usaha khususnya bagi perempuan pedesaan. Pengembangan usaha ini dapat meningkatkan potensi perekonomian pedesaan dan memberikan kontribusi bagi peningkatan pendapatan 
rumahtangga perempuan dan peningkatan pendapatan daerah.

Faktor lain yang menunjang berkembangnya usaha ini yaitu letak/posisi Desa Rasi Kecamatan Ratahan, merupakan wilayah perlintasan antar kabupaten di Propinsi Sulawesi Utara, maupun antar propinsi. Biskuit ini menjadi salah satu jenis oleh-oleh/buah tangan bagi masyarakat yang melintasi wilayah tersebut. Oleh karena itu, kue biskuit terbuat dari tepung pisang goroho ini perlu mendapat perhatian karena dapat menjadi ciri khas atau ikon bagi Kabupaten Minahasa Tenggara khususnya dan mampu mengangkat citra makanan lokal/tradisional di Sulawesi Utara pada umumnya.

Usaha pembuatan dan penjualan kue biskuit kebanyakan diusahakan oleh kaum perempuan dikategorikan sebagai usaha sektor informal karena memiliki ciri-ciri antara lain :

1. Seluruh aktivitasnya bersandar pada sumber daya lokal. Bahan-bahan (tepung pisang goroho, dan gula merah/aren) dan sarana (cetakan, tungku dan kayu bakar) dalam pembuatan kue biskuit tersedia di sekitar lokasi penjualan.

2. Ukuran (skala) usaha umumnya kecil dan aktivitasnya merupakan usaha keluarga.

3. Menggunakan teknologi yang sederhana, bahkan teknologinya masih tradisional dan bersifat padat karya.

4. Modal yang digunakan untuk berusaha dan perputaran usaha relatif kecil.

5. Tenaga kerja yang bekerja umumnya adalah berasal dari anggota keluarga.

6. Aktivitas mereka dalam sektor ini belum/tidak menggunakan bantuan atau fasilitas yang disediakan oleh pemerintah.

7. Sebagian besar produksi dan jasa mereka dinikmati oleh masyarakat berpenghasilan rendah serta sebagian kecil masyarakat golongan menengah.
Kebanyakan pengusaha kue biskuit yang ada di lokasi ini dapat dikategorikan sebagai usaha berskala 'kecil'. Modal awal membuka usaha kue biskuit rata-rata 1 juta rupiah untuk bangunan kios dan sarananya. Untuk usaha kecil penjualan kue biskuit biasanya menghabiskan adonan rata-rata 1 $\mathrm{kg}$ tepung pisang goroho, gula merah 1 buah, 0,03 g baking powder, 0,2 $\mathrm{g}$ kayu manis, $0,10 \mathrm{~g}$ vanili, $1 \mathrm{~g}$ garam, $50 \mathrm{~g}$ mentega hasil yang diperoleh yaitu 150 biji (15 kotak). Di dalam satu kotak berisi 10 biji. Harga penjualan per kotak yaitu 10.000 rupiah. Jadi, apabila semua kotak terjual habis, maka pedagang akan memperoleh harga omzet sebesar Rp. 150.000. Biaya yang diperlukan dalam pembuatan kue biskuit sebanyak 150 biji itu sebesar Rp. 75.000, sehingga keuntungan yang diperoleh sekitar 50\% (Hasil wawancara dengan calon Mitra, 2014).

Upaya untuk meningkatkan omzet pengusaha berskala kecil sulit dilakukan. Hal itu terjadi oleh karena adanya kendala utama yaitu: banyaknya jumlah pengusaha kue biskuit yang ada di sekitar lokasi ini yaitu 6 usaha/kios yang bersaing menawarkan produk yang sama. Rasa kue biskuit yang dibuat pengusaha sama yaitu rasa original pada semua kios. Tidak ada variasi rasa yang berbeda yang menyebabkan konsumen tidak tertarik membeli produk dalam jumlah yang lebih banyak.

Namun diantara pengusaha kue biskuit 'kecil' tersebut, ada 2-3 pengusaha yang memiliki usaha berskala lebih 'besar' dibandingkan dengan pengusaha lainnya. Pengusaha yang lebih besar ini beromzet penjualan yang lebih tinggi dalam satu hari, meskipun produk yang ditawarkan masih satu rasa biskuit (rasa original). Rata-rata jumlah bahan baku yang diolah sebesar 10 liter tepung, sehingga jumlah kue biskuit yang dihasilkan mencapai 750 biji (75 
kotak). Dengan demikian laba bersih yang dapat diperoleh juga lebih besar.

Upaya yang dapat dilakukan untuk meningkatkan omzet penjualan suatu produk yaitu dengan memperbaiki kotak/dos kemasan suatu produk. Kotak kemasan suatu produk bukan hanya berfungsi untuk menjaga kebersihan dan bentuk suatu produk, melainkan juga dapat berfungsi sebagai ajang promosi bagi produk tersebut. Oleh karena itu, kotak kemasan suatu produk harus menarik, berkualitas baik dan informatif.

Pengusaha kue biskuit baik yang berskala kecil maupun besar di Desa Rasid masih mengemas produk kue biskuit dalam kotak yang banyak diperjual belikan di pasaran. Kotak kemasan yang digunakan kurang berkualitas (tipis) sehingga memungkinkan terjadi kerusakan dalam perjalanan. Selain itu tidak ada informasi nama usaha, nama produk dan informasi lainnya pada kotak kemasan. Padahal kotak kemasan yang berkualitas dan informatif dapat menjadi promosi untuk memperkenalkan usaha dan dapat meningkatkan omzet penjualan.

Permasalahan tersebut tampaknya belum terpikirkan oleh pengusaha kue biskuit yang ada di desa ini. Hal ini terjadi karena kurangnya pengetahuan pengusaha kue biskuit mengenai hal-hal yang berkaitan dengan pengelolaan/manajemen usaha yang baik dan benar, termasuk pengelolaan keuangan. Melalui program training/pelatihan bagi mitra usaha kue biskuit, mereka akan menjadi pengusaha yang memiliki skills yang lebih baik, mampu menciptakan produk baru/modifikasi rasa, bentuk, warna dan meningkatkan omzet penjualan produk.

Dengan adanya mitra dalam jumlah yang cukup banyak di lingkungan desa Rasid, diharapkan mitra dapat mengembangkan usahanya serta dapat mengembangkan ketrampilan yang telah mereka peroleh kepada lingkungannya, sehingga lingkungan usaha di wilayah tersebut nantinya menjadi berkembang. Dengan adanya perkembangan usaha ini diharapkan nantinya bisa menumbuh kembangkan perekonomian di wilayah Desa Rasid khususnya dan Kabupaten Minahasa Tenggara pada umumnya.

Dari analisis situasi mitra tersebut di atas maka dirumuskan permasalahan sebagai berikut:

1. Produk yang dibuat dan ditawarkan semua pengusaha kue biskuit di desa Rasid hanya satu macam rasa saja yaitu rasa original biskuit, tidak ada variasi rasa, bentuk dan warna yang mampu menarik konsumen untuk membeli lebih banyak produk. Sehingga upaya untuk meningkatkan omzet mengalami hambatan.

2. Pengusaha kue biskuit menggunakan kotak kemasan produk yang tidak memiliki informasi (nama usaha, pemilik atau lokasi) sama sekali dari kotak kemasan tersebut. Jadi pengemasan produk terkesan masih asalasalan atau seadanya yaitu dengan menggunakan kotak kemasan yang banyak dijual di pasaran. Konsumen tidak dapat mengetahui nama, lokasi atau bahkan telepon yang bisa dihubungi untuk melakukan pemesanan produk.

3. Pengusaha kue biskuit yang berada di desa Rasid sebagian besar menggunakan tepung terigu, belum menggunakan tepung yang berasal dari pisang goroho dan memiliki tingkat pendidikan relatif rendah. Mitra pada umumnya adalah ibu rumah tangga yang belum memiliki pengetahuan tentang cara pembuatan tepung yang berasal dari tanaman pisang goroho dan cara pengelolaan usaha yang 
mandiri dan cara pengelolan keuangan (cash flow) dengan baik.

Menyikapi permasalahan tersebut di atas, maka diperlukan suatu tindakan nyata pemberdayaaan kelompok pengusaha kue biskuit dalam pengelolaan usaha yang lebih baik dengan orientasi pasar lebih luas, agar pengusaha termotivasi dan bertindak mandiri maupun secara berkelompok. Tindakan nyata yang dapat dilakukan adalah meningkatkan pengetahuan dan keterampilan kelompok pengusaha kue biscuit cara membuat tepung yang berasal dari pisang gorohyo melalui pengelolaan usaha, menciptakan variasi produk dan penanganan kotak kemasan produk. Upaya tersebut diharapkan akan meningkatkan omzet penjualan dan meningkatkan keuntungan bersih yang pada gilirannya meningkatkan kesejahteraan masyarakat di Desa Rasid dan sekitarnya.

\section{Solusi Yang Ditawarkan}

Tantangan bagi dunia usaha agar kondusif bagi upaya-upaya pemberdayaan dan pengembangan Usaha Kecil dan Menengah (UKM) mencakup aspek yang luas, antara lain: 1) peningkatan kualitas sumber daya manusia dalam hal kemampuan manajemen, organisasi dan teknologi; 2) kompetensi kewirausahaan; 3) akses yang lebih meluas terhadap permodalan, informasi teknologi dan pasar, serta faktor masukan produksi lainnya; 4) iklim usaha yang sehat yang mendukung tumbuhnya inovasi dan kewirausahaan, praktek bisnis berstrand internasional serta persaingan yang sehat.

Untuk memberdayakan usaha kue biskuit yang ada di Desa Rasid perlu pemberlakuan skala prioritas aspek utama yang akan dilakukan dalam program pengabdian (PKM) ini. Berdasarkan analisis situasi dan permasalahan dalam usaha pengelolaan kue biskuit tersebut, maka program yang disepakati bersama mitra, ada 3 (tiga) aspek utama yaitu (1) Cara membuat tepung dengan bahan pisang goroh (2) modifikasi produk dan pembuatan/design kulit kotak kemasan dan (3) manajemen pengelolaan usaha dan keuangan. tiga aspek yang akan dilaksanakan ini dilakukan secara berkelompok dan waktu realisasi program sesuai jadwal yang direncanakan. Program kegiatan yang akan dilaksanakan berupa pelatihan/materi teoritis dan praktek di salah satu tempat usaha kue biskuit di Desa Rasid yang sudah disepakati untuk pelaksanaan seluruh kegiatan.

Metode yang digunakan dalam pelatihan adalah metode pelatihan partisipatif, yaitu melibatkan sebanyak mungkin peran serta mitra dalam kegiatan ceramah, diskusi, dan praktek rancangan dan cipta karya. Program yang sudah disepakati dengan mitra pengusaha kue biskuit di Desa Rasid Kecamatan Minahasa Tenggara dilakukan dengan metode sebagai berikut:

1. Training/pelatihan cara membuat tepung pisang goroho dan modifikasi/diversifikasi rasa produk.

2. Perancangan (Design) tampilan kulit dan pembuatan kotak kemasan produk.

3. Training/pelatihan Pengelolaan Usaha.

4. Training/pelatihan manajemen keuangan bagi peserta.

Pelaksanaan kegiatan dan evaluasi adalah sebagai berikut:

\section{Pelaksanaan Kegiatan:}

a). Persiapan: kegiatan yang dilakukan mencakup.

1. Koordinasi dengan stakeholder terkait, seperti: instansi atau pemerintah Desa Rasid.

2. Menentukan satu orang sebagai koordinator lapangan untuk memudahkan komunikasi selama kegiatan berlangsung.

3. Mensosialisasikan mitra yang akan mengikuti kegiatan yaitu berdasakan besarnya skala usaha, 1- 2 orang dari 
pengusaha kue biskuit skala 'besar' dan 5-8 orang dari pengusaha kue biskuit skala 'kecil'.

4. Persiapan dan penyusunan bahan/modul/materi pelatihan.

b). Pemberian pelatihan:

1. Pendampingan/pelatihan teknik pembuatan tepung pisang goroho dan produk kue biskuit dengan modifikasi rasa (selain rasa original), yang dikerjakan bersama oleh mitra dan tim pelaksana . Tim pelaksana PKM bertindak sebagai pengarah dalam menciptakan rasa baru yang dibuat bersama dengan mitra. Selanjutnya, produk dengan rasa baru ini diputuskan bersama untuk dijadikan produk baru untuk dipasarkan dalam usaha kue biskuit ini. Pelatihan teknik pembuatan produk kue biskuit rasa 'baru' ini dilakukan beberapa kali sampai diperoleh 2-3 rasa baru yang disepakati oleh mitra dan tim pelaksana kegiatan PKM.

2. Pendampingan perencanaan rancangan/design kulit kotak kemasan produk yang ditawarkan oleh Tim Pelaksana PKM kepada mitra untuk dipertimbangkan. Bila rancangan kulit kotak kemasan sudah disetujui, maka kotak kemasan akan dibuat untuk selanjutnya digunakan dalam pengemasan produk.

3. Pelatihan manajemen/pengelolaan usaha, teknik produksi, strategistrategi pemasaran dalam bentuk pelatihan teori praktis.

4. Pendampingan/pelatihan manajemen/pengelolaan keuangan dalam bentuk pelatihan teori prakis dan praktek pembuatan Cash flow usaha.

\section{Evaluasi kegiatan:}

Setelah melaksanakan kegiatan training/pelatihan dari seluruh rangkaian program kegiatan, peserta akan dievaluasi:

1. Pada akhir program pelatihan, peserta secara individu diwajibkan membuat tepung dari pisang goroho, produk hasil pelatihan berupa modifikasi rasa biskuit yang sudah disepakati.

2. Pada akhir program peserta wajib menunjukkan hasil praktek penyusunan laporan keuangan bulanan.

3. Mitra yang dianggap berhasil dalam menyerap dan mentrasfer ilmu dan keterampilan yang telah diberikan melalui program kegiatan $\mathrm{IbM}$ ini diberikan penghargaan (reward) berupa alat pemanas (Oven) yang digunakan sebagai wadah membakar produk yang telah dibuat.

\section{Kegiatan yang telah dilakukan}

Berdasarkan uraian tersebut, maka kegiatan program yang telah dilakukan diuraikan pada Tabel 1. 
Tabel 1. Kegiatan

\begin{tabular}{|l|l|l|l|}
\hline No & \multicolumn{1}{|c|}{ Kegiatan } & \multicolumn{1}{c|}{ Peserta } & \multicolumn{1}{c|}{ Pelaksana } \\
\hline 1 & $\begin{array}{l}\text { Pelatihan dan demonstrasi } \\
\text { tentang cara pembuatan tepung } \\
\text { dari bahan pisang goroho }\end{array}$ & $\begin{array}{l}\text { Kelompok PKK } \\
\text { Lingkungan 2 dan 3 }\end{array}$ & $\begin{array}{l}\text { Tim Pengabdian dan Lurah } \\
\text { (Desa Rasid) Ratahan }\end{array}$ \\
\hline 2 & $\begin{array}{l}\text { Memberikan pelatihan dan } \\
\text { demonstrasi tentang cara } \\
\text { pembuatan kue biscuit dari } \\
\text { pisang goroho. }\end{array}$ & $\begin{array}{l}\text { Kelompok PKK } \\
\text { Lingkungan 2 dan 3 }\end{array}$ & Tim Pengabdian \\
\hline 3 & $\begin{array}{l}\text { Menberikan pelatihan cara dan } \\
\text { waktu untuk peking kue biscuit }\end{array}$ & $\begin{array}{l}\text { Kelompok PKK } \\
\text { Lingkungan 2 dan 3 }\end{array}$ & Tim Pengabdian \\
\hline 4 & $\begin{array}{l}\text { Memberikan pelatihan } \\
\text { managen keuangan }\end{array}$ & $\begin{array}{l}\text { Kelompok PKK } \\
\text { Lingkungan 2 dan 3 }\end{array}$ & Tim Pengabdian \\
\hline
\end{tabular}

\section{Kontribusi Partisipasi Mitra}

Tahap Pertama: Memberikan pelatihan dan demonstrasi tentang cara pembuatan tepung dari pisang goroho

Partisipasi Kelompok PKK: Masingmasing kelompok PKK memperhatikan dan melakukan cara pembuatan tepung pisang ngoroho

Tahap Kedua: Memberikan pelatihan dan1 demonstrasi cara pembuatan biscuit dari tepung pisang goroho

Partisipasi Kelompok PKK: Masingmasing kelompok PKK mengolah adonan kue dari tepung pisang goroho dan membuat cetakan.

Tahap Ketiga: Memberikan pendamping dan pelatihan tentang managemen keuangan.

Partisipasi Kelompok PKK: Masingmasing kelompok PKK mempraktekkan sesuai dengan metode yang telah diberikan pada pelatihan.

Tahap Keempat: Melakukan monitoring dan evaluasi pada seluruh kegiatan secara bertahap. Kegiatan ini bertujuan untuk mengetahui tingkat pemahaman dan penerapan tentang materi yang telah diberikan, serta permasalahan yang dihadapi dalam pelaksanaan kegiatan tersebut.
Partisipasi Kelompok PKK: Masingmasing kelompok PKK melaporkan kendala dan masalah yang terjadi dan bersama-sama dengan tim pelaksana program mencari solusinya.

\section{TARGET LUARAN:}

Target luaran dari kegiatan PKM ini adalah:

Semua mitra pengusaha kue biscuit (peserta pelatihan/training) dapat membuat tepung yang berasal dari pisang goroho dapat membuat produk modifikasi rasa baru yang telah dipraktekkan.

2. Semua mitra pengusaha kua biskuit (peserta pelatihan/training) menggunakan kotak kemasan produk yang sudah dirancang bersama dalam pelatihan ini.

. Sebagian besar mitra pengusaha kue biskuit (60\% peserta pelatihan/training) mampu menerapkan manajemen keuangan dan strategi-strategi yang sudah diperoleh dalam pelatihan.

E. SOLUSI PERMASALAHAN

E. 1 Pelatihan, Demonstrasi dan Pelatihan Cara Pembuatan Tepung Pisang Goroho E. 1. 1 Landasan Teori 
Berdasarkan penelitian yang pernah dilakukan oleh Sondakh (1990), tepung pisang goroho mengandung nilai gizi Pati $80,89 \%$, Prtein $2,89 \%$, Lemak 0,67 \%, dan serat kasar $2 \%$. Dari data tersebut terbukti bahwa potensi pengembangan pisang goroho sebagai alternatif makanan bersumber karbohidrat karena mengandung $80,89 \%$ pati, dan juga alternatif mengolah pisang menjadi tepung merupakan salah satu langkah untuk menghindari kerugian pasca panen bagi para petani pisang. Buah pisang memang merupakan salah satu jenis buah yang busuk dalam beberapa waktu. Selain itu, jumlah produksinya juga cukup melimpah dengan demikian keberadaannya jauh lebih tinggi ketimbang buah lain, dengan mengolahkannya menjadi tepung pisang tentu akan menambah nilai jual.

Sekarang ini tepung pisang digunakan untuk berbagai produk olahan, pengganti tepung terigu, formulasi pada kue tradisional seperti kue basah atau kering misalnya kue tradisional biskuit. Biskit adalah sejenis makanan yang terbuat dari tepung terigu dengan penambahan bahan makan lain, dengan proses pemanasan dan percetakan. Sebagian besar biskuit yang ada dipasar menggunakan bahan baku tepung terigu yang mempunyai kandungan protein yang rendah (Aninomous, 2012). Penggunaan tepung non terigu untuk pembuatan kue tradisional dan biskuit saat ini banyak dikembangkan, terutama untuk jenis biskuit bebas glutein (gluten free biscuit).

Berdasarkan kenyataan bahwa pisang goroho sudah menjadi suatu kebutuhan dari masyarakat, maka pada pengabdian ini pengembangan pembuatan kue tradisional dan biskuit yang diharapkan bisa menjadi alternatif sebagai makanan selingan yang memiliki nilai lebih dengan menggunakan tepung pisang goroho sebagai bahan makanan spesifik lokal di Sulawesi Utara.

\section{E. 1. 2 Proses Pembuatan Tepung Pisang Goroho}

Proses pembuatan tepung pisang dilakukan dengan pengeringan, sebelum dikeringkan pisang yang sudah dipotong tipis-tipis menggunakan slicer direndam dahulu dengan air panas. Tujuan dari proses ini adalah untuk mengendalikan reaksi pencoklatan bagi ensimatis maupun non ensimatis. Pengeringan pisang menggunakan cahaya matahari. Pengeringan pisang dilakukan selama 3 hari hingga kadar air $<10 \%$. Hal ini didasarkan pada SNI 013841-1995 tentang tepung pisang yang menyatakan bahwa kadar air dalam tepung pisang maksimal adalah $12 \%$. Setelah proses pengeringan selesai, pisang dihancurkan dengan blender dan diayak dengan ayakan 80 mesh.

\section{E. 1.3 Cara Pembuatan Biskuit Dari Pisang Goroho}

Biskuit adalah produk jajanan renyah yang dibuat dengan cara dipanggang, biskuit juga dikenal dengan nama kue kering, simpel untuk dibawa kemana saja. Untuk menambah cita rasa biskuit, agar lebih enak dan beragam bisa ditambahkan coklat, keju, buah-buahan dan rempah-rempah lain yang membuat rasanya menjadi beragam. Bahan baku dalam proses pembuatan biskuit tetap mamakai bahan baku tepung terigu tetapi tepung terigu diganti dengan tepung pisang goroho. Bahan-bahan yang diperlukan adalah: 1) $100 \mathrm{~g}$ mentega, 2) $200 \mathrm{~g}$ tepung pisang goroho, 3) $100 \mathrm{~g}$ susu bubuk, 4) 100 g gula aren, 5) 2 buah telur, 5) vanila secukupnya, 6) 1/2 sendok makan soda kue.

Cara membuatnya. 1) lelehkan mentega dengan gula aren, kemudian campur dengan telur agar adonan lebih berstektur, 2) masukkan semua bahan dan aduk sampai adonan menjadi kulis, jika adonan sudah tercampur dengan rata, diamkan adonan dalam suhu ruangan agar mengembang, 3) setelah beberapa jam panaskan oven 400 derajat Farenheit dan 
letakkan adonan di atas oven dan dipanggang sampai matang selama 30 menit.

\section{F. PENUTUP DAN SARAN \\ F. 1 Penutup}

Penerapan pengabdian kemitraan masyarakat (PKM) melalui pelatihan pembuatan tepung pisang goroho (Musa acuminata, SP) dan cara pembuatan kue biscuit dari tepung pisang goroho pada kelompok PKK Desa Rasi Kecamatan Ratahan Kabupaten Minahasa Tenggara dapat dianggap berhasil dengan indikator sebagai berikut:

- Semua program kegiatan yang direncanakan (Pelatihan pembuatan tepung terigu dan cara pembuatan biskuit) terlaksana dengan baik sesuai rencana dan disertai dengan dukungan dan partisipasi ibu-ibu PKK secara penuh.

- Pelatihan pembuatan tepung pisang goroho dapat dilakukan di tempat demonstrasi (Kantor Desa Rasi Ruang PKK)

- Semua tahap kegiatan dalam pelatihan pembuatan tepung pisang goroho dan cara pembuatan biskuit dilaksanakan dengan baik sesuai anjuran yang diberikan pada pelatihan.

- Hasil tepung pisang goroho dan kue biskuit diperoleh cukup baik, rasanya yang enak dan disukai oleh ibu-ibu PKK serta masyarakat yang ada di Sulawesi Utara.

\section{F. 2 Saran/Rekomendasi}

Berdasarkan hasil analisis tim merekomendasikan/menyarankan kepada mitra atau Ibu-ibu PKK desa Rasi di Kecamatan ratahan sebagai berikut:

- Ibu-ibu PKK di desa Rasi perlu melakukan sosialisasi secara kontinyu dan terus menerus untuk merubah pola pikir ibu-ibu mengenai pemanfaatan pisang goroho bukan hanya untuk direbus atau digoreng tetapi bagaimana kita memanfaatkan pisang goroho lebih meningkatkan nilai jualnya.

Ibu-ibu PKK di desa Rasi perlu melakukan sosialisasi secara kontinyu dan terus menerus mengenai cara pembuatan tepung pisang goroho agar dapat meningkatkan ekonomi kelurga dan kesejahteraan keluarga.

\section{DAFTAR PUSTAKA}

Adi Pidekso. 2003. Profil Upaya Perempuan dalam Pemberdayaan Usaha EkonomisProduktif Sektor Informal pada Konteks Nilai Pemberdayaan Diri dalam Jurnal Pendidikan Nilai. Kajian Teori, Praktik, dan Pengajarannya. Tahun 9, Nomor 1, November 2003, Universitas Negeri Malang (UM) dalam http://www.malang.ac.id/jurnal/lain/nil ai/ 2003.htm.

Kartasasmita, G. 2001. Membangun ekonomi rakyat untuk mewujudkan Indonesia baru yang kita cita-citakan. Disampaikan di depan Gerakan Mahasiswa Pasundan, Bandung, 27 September 2001

Sethuraman, SV. 1985. Sektor Informal di Negara Sedang Berkembang. Yogyakarta: PT. Gramedia.

Supenti, Titin. 2007. Data dan Analisis. Rendahnya Posisi Wanita di Pasar Kerja.

dalam Warta Ketenagakerjaan. Pusat Data dan Informasi Ketenagakerjaan. dalam

http://www.nakertrans.go.id/majalah_b uleti/

warta_naker/edisi_8/data_posisi_perem puan.php 


\section{LAMPIRAN}
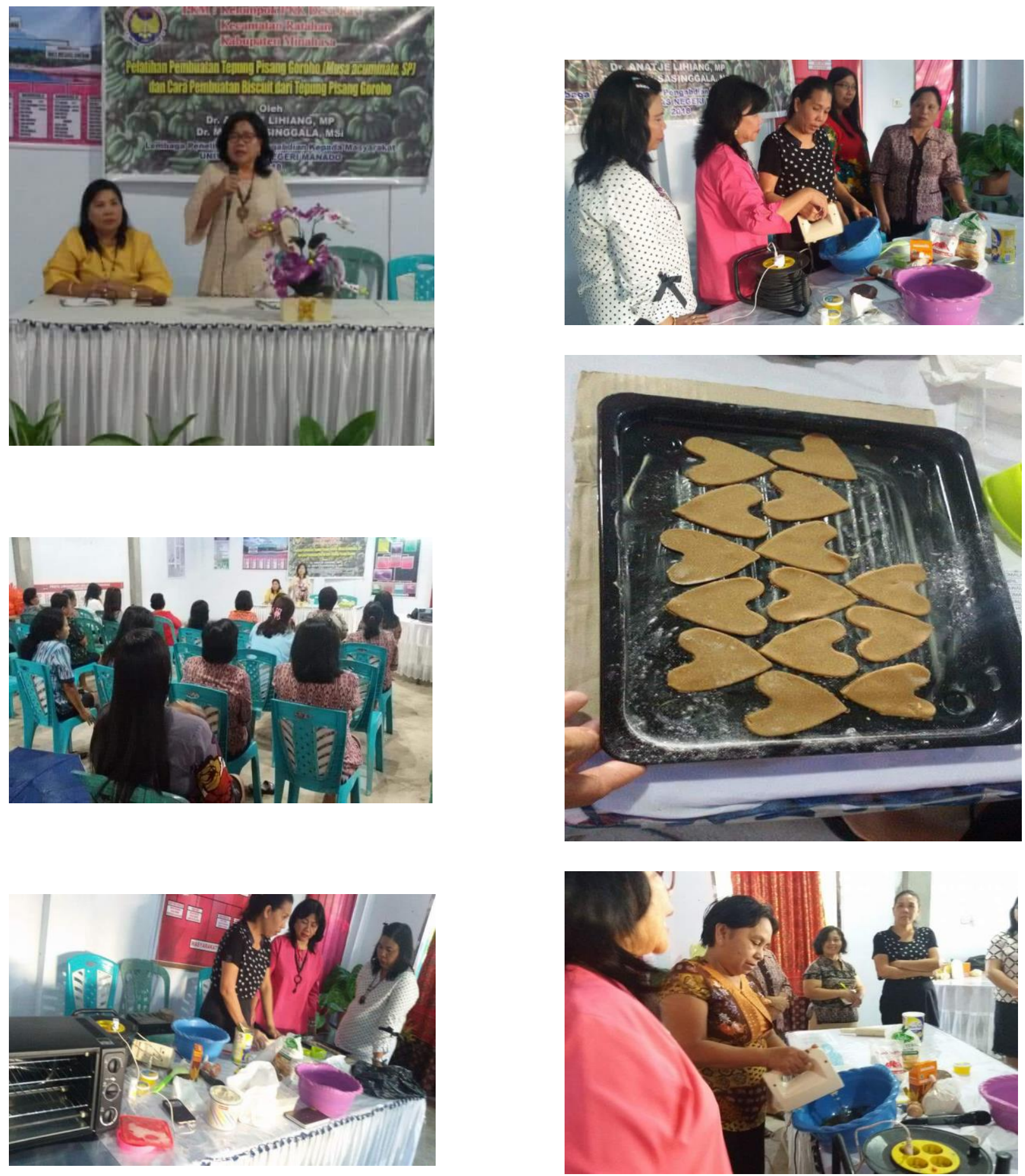